\title{
CONTINUING THE DIALOGUE ON THE CANADIAN CARCERAL STATE
}

\author{
The Double Punishment of \\ Criminal Inadmissibility for Immigrants \\ Souheil Benslimane and David Moffette
}

\begin{abstract}
Canada bars non-citizens from entering or staying in the country for a number of reasons, including for what immigration law treats as "criminality", "serious criminality" or "organized criminality". Criminal inadmissibility-including for rather minor criminalized acts-raises a number of concerns for those who are targeted, but also for border criminologists, prisoners' rights activists and migrant justice organizers. In this article, we discuss inadmissibility for "criminality" and "serious criminality" as: 1) a populist rhetorical move put forth by politicians promoting tough-on-crime / tough-on-immigration policies; 2) a form of double punishment that starts before deportation even takes place (and regardless of whether it does); and 3) a discretionary tactic in the policing toolbox used to incapacitate people who are deemed undesirable. We illustrate the consequences of criminal inadmissibility by drawing from the experience of one of the co-authors who is facing deportation on this ground.
\end{abstract}

Keywords: abolition; double punishment; criminalization; immigration; inadmissibility; Canada

\section{INTRODUCTION}

Immigration law and criminal law are distinct, follow different procedures and standards of proof, and apply to different groups of people. While criminal law is deployed disproportionately according to class, race and gender (Chan and Chunn, 2014), it is officially supposed to apply to everyone. In contrast, immigration law is designed to apply only to nonnationals, that is, anyone who is not a Canadian citizen, regardless of the number of years this person has lived in Canada or whether they are a permanent resident. For this reason, it has been described as a form of apartheid (Richmond, 1994; Sharma, 2012), that is, a restrictive type of law that applies only to a portion of the population. However, while immigration law and criminal law are separate legal regimes, they overlap and intersect 
in a number of ways, including through the immigration consequences of criminal sentences. ${ }^{1}$ Criminal territorial inadmissibility is a good example of such intersections.

Indeed, Canada bars non-citizens from entering or staying in the country for a number of reasons, ranging from poor health and disability to "terrorism" (El-Lahib, 2015; Bond, 2017; Wilton et al., 2017). With regard to questions of criminality and security, Canadian officials can exclude asylum seekers from obtaining refugee protection if they have allegedly committed human rights violations (as per Article 1F of the Refugee Convention of 1951), but can also bar asylum seekers and immigrants through a number of other inadmissibility clauses found in the Immigration and Refugee Protection Act (IRPA). The grounds include "security" (e.g. espionage, terrorism, etc.) and "human or international rights violations" (e.g. war crimes), but also what the IRPA describes as "criminality", "serious criminality", and "organized criminality".

Criminal inadmissibility - including for rather minor criminalized acts raises a number of concerns for those who are targeted, but also for border criminologists, prisoners' rights activists and migrant justice organizers. In this article, we discuss inadmissibility for what the IRPA describes as "criminality" and "serious criminality". We analyze the use of this form of inadmissibility as: 1) a populist rhetorical move put forth by politicians promoting tough-on-crime / tough-on-immigration policies; 2) a form of double punishment (Sayad, 2004) that starts before deportation even takes place (and regardless of whether it does); and 3) a discretionary tactic in the policing toolbox used to incapacitate people who are deemed undesirable. This allows us to provide a critique of criminal inadmissibility and argue, in the conclusion, that it should be abolished. While we describe the law and analyze its consequences in general terms, we also provide examples taken from the lived experiences of one of the co-authors, Souheil, ${ }^{2}$ who is considered inadmissible on this ground.

\section{LOWERING THE THRESHOLD OF INADMISSIBILITY AS A POPULIST STRATEGY AGAINST NON-CITIZENS}

Our first point is that the history of criminal inadmissibility suggests that it is a form of very harsh punishment that was put forth as part of a populist 
strategy of promoting tough-on-crime / tough-on-immigration policies. Let us start with a description of the legal definition of criminal admissibility to make our argument.

Currently, section 36(1)(a) of the IRPA states that "A permanent resident or a foreign national is inadmissible on grounds of serious criminality for [...] having been convicted in Canada of an offence under an Act of Parliament punishable by a maximum term of imprisonment of at least 10 years, or an offence under an Act of Parliament for which a term of imprisonment of more than six months has been imposed". Section 36(2) (a) states that "a foreign national is inadmissible on grounds of criminality for [...] having been convicted in Canada of an offence under an Act of Parliament punishable by way of indictment, or of two offences under an Act of Parliament not arising out of a single occurrence". ${ }^{3}$

Four things are worth highlighting that point to the harshness of this law: 1) inadmissibility for "serious criminality" also applies to permanent residents; 2) there is very limited access to appeal or stay the decision for "serious criminality"; 3) "mixed offences" are considered as though they are indictable offences and lead to the same consequences; and 4) the criteria to classify an act as "serious criminality" is so low that it applies to what many would consider rather minor offences. This tough-on-crime / tough-on-immigration policy is part of a broader populist strategy aimed at pitting communities against each other, while advancing socially and fiscally conservative policy changes that are detrimental to most of us.

\section{INADMISSIBILITY FOR "SERIOUS CRIMINALITY" AND PERMANENT RESIDENTS}

Section 36(1), which addresses so-called "serious criminality", also applies to permanent residents who might have spent most of their life in Canada and who, for various reasons, have not applied for or received citizenship. This is important because permanent residents are people who have decided to stay in this country and who hardly differ from citizens - especially those who have a similar experience of migration and racism - except for their lack of formal citizenship, but whose status is mobilized as a way to treat them differently. Souheil's experience is a good example:

I did not apply for citizenship because my family had feared that my application would have been denied. Permanent residents need to be on 
Canadian soil for three out of five years to be eligible to apply for Canadian citizenship. ${ }^{4}$ During that mandatory period, I accumulated a criminal record. The charges I pleaded guilty to prior to being admissible for a citizenship application were breaches of probation, simple possession of cannabis, assault on a police officer, and public intoxication. While I was a young man not unlike most, I think that my oppressable identities defined along race, age, class, and immigration status contributed greatly to my criminalization.

Indeed, being a Brown-Arab teenager was a reason to be targeted by the police in Gatineau for illegal search and seizure. Race-based discriminations are not only isolated happenstances consequential of the behaviour of a few racist police officers acting out of stereotypical beliefs. Substantial bodies of evidence demonstrate that racial profiling is a systemic issue that plagues policing practices in Canada (Gurmukh, 2018). We also know that, for example, the higher number of simple cannabis possession charges in disadvantaged and racially diverse neighborhoods was concomitant with "high levels of carding" (ibid, 2018: 71). ${ }^{5}$ During multiple instances, the Gatineau City Police Department officers who were in patrol in the Plateau and the Mont-Bleu neighbourhoods targeted youth who were hanging out at city parks. Deploying officers to these spaces led to the criminalization of many friends and acquaintances who would have otherwise stayed record-free if they were not stopped and searched by the police. Every time I walked outside, I felt surveilled by Gatineau's overwhelmingly white police force. I was more likely to be subject to carding police practices. This increased my chances of becoming criminalized as a racialized youth and, by extension, illegalized as an immigrant.

This points to structural conditions that limit access to citizenship and a more secure presence in the country, doubled-up with racialized policing that increases scrutiny and the risk of being criminalized. To this, we also need to add the structural inequality that limits economic opportunities for many immigrant families, which can also contribute to marginalization and criminalization. On this point, Souheil remarks:

Coming from a family that was well-off in Morocco and that became socio-economically demoted in Canada had concrete consequences on 
my criminalization. Being poor pushed me to 1) engage in criminalized behaviours to compensate for the financial precarity and to fulfill socially accepted and promoted goals while lacking the means needed to attain them, and 2) plead guilty to charges that I could have challenged at trial if I knew my rights upon arrest and had received advice from a counsel that is not paid by the state, knowing that "legal-aid" lawyers are overburdened with files, are underpaid, and sometimes cannot allot the necessary time to give non-paying clients thorough legal advice. Furthermore, given my parents' scarce financial resources, they did not want to spend the fees for a citizenship application only for their son to be denied. Other than the guidelines of hard-to-navigate immigration forms, my family and I did not receive any formal advice as to whether it was possible to apply for citizenship if one has a criminal record. If my family enjoyed greater financial freedom or if the citizenship application were free of charge, we would have applied for my citizenship. My family's limited budget, the expensive citizenship application, and the lack of knowledge about immigration processes deterred my family from ensuring that I apply for citizenship.

This shows how obtaining citizenship can be hampered by one's identity, as well as by social and material conditions, which are affected by race, gender, class, religion and age, among other factors. In this case, the over-policing and subsequent criminalization of racialized people, the de-skilling of many immigrant workers that leads to difficult financial positions, alongside the bureaucratic and expensive immigration and citizenship procedure had compounded effects on access to citizenship despite a long presence in the country. The fact that even permanent residents can be deemed inadmissible on the grounds of "serious criminality" is thus troubling.

\section{LIMITED ACCESS TO AN APPEAL PROCESS IN CASES OF "SERIOUS CRIMINALITY"}

The second point worth noting is that there is limited recourse to appeal or stay a removal order when deemed inadmissible for so-called "serious criminality", which means that people can be taken away from their families and friends, and deported to a country they may hardly know without access to the type of procedural guarantees that they would get in a criminal law 
context. Indeed, while a permanent resident deemed inadmissible can generally appeal a removal order, section 64(1) of the IRPA explicitly states that "No appeal may be made to the Immigration Appeal Division by a foreign national or their sponsor or by a permanent resident if the foreign national or permanent resident has been found to be inadmissible on grounds of security, violating human or international rights, serious criminality or organized criminality". ${ }^{6}$ In this context, all that is left is to request a judicial review of the decision or to file a Pre-Removal Risk Assessment in the hope of obtaining a stay of the removal (Tavadian, 2010).

The absence of concrete avenues to effectively appeal the decision exposes removable migrants to great physical and psychological harm. Here again, Souheil's story illustrates this point well:

Many of the friends with whom I spent time in various Canadian jails and prisons told me that they were so far-removed from their cultures that integrating into the countries to which they were being deported generated extreme anxiety and proved extremely arduous. Some of those people came to Canada at ages as young as 1 and were deported in their late twenties and early thirties. Taha, ${ }^{7}$ my close friend who was deported, testified that when he arrived to his country of citizenship he did not feel at home and was overwhelmed by despair. He was extremely confused and felt out of place. Consequently, he mobilized all his efforts and resources to flee Morocco to a European country. Once he crossed the Mediterranean Sea, he reunited with the familiarity of the "Western" cultural context.

As this case shows, removal may expose the deportees to cultural shock, alienation, risk and even death. Some of them, like Taha, would go as far as risking their lives to cross treacherous seas in life-threatening conditions after being deported. The legal framework denying the right to appeal a removal order to those sentenced to a term of imprisonment of six months or more appears disproportionately harsh given the possible life-threatening consequences of a deportation.

\section{When "Mixed Offences" Become "Indictable Offences"}

The third point worth noting is that "mixed offences" that could be prosecuted by indictment or summarily are deemed to be indictable offences for the purpose of immigration law, regardless of how they were prosecuted 
criminally. This means that the flexibility written into criminal law - which allows for a different type of prosecution based on an assessment of the seriousness of the offence - is rendered irrelevant here, and people sentenced for a "mixed offence" are treated as though it were an indictable offence. When translated into immigration law, "mixed offences" are elevated to the status of an indictable offence and treated as harshly.

\section{When "Serious Criminality" Applies to Minor Offences"}

Finally, the fourth point is that there are many arguably minor offenses that may lead to inadmissibility. The category of "criminality" (see Section 36(2) (a)) can lead to the removal of a temporary resident who has committed any two offences at different times. But the category of "serious criminality" (see section 36(1)(a)) can lead to the removal of temporary and permanent residents alike, thus casting a wide net. As a reminder, inadmissibility for "serious criminality" applies to people who have been found guilty of an offence punishable by a maximum of ten years in prison, or for which a term of imprisonment of six months or more has been imposed. In many cases, this applies to acts that are not very harmful or serious.

Indeed, there are many offences punishable on the books by a maximum of ten years in prison. Here are some examples: Someone who gets into a fight leaving a bar and throws a single punch that leads to someone's nose being broken may be found guilty of "assault causing bodily harm" (Criminal Code, section 267(b)). Someone who steals an ATV to go for a joy ride may be convicted of "motor vehicle theft" (Criminal Code, section 333.1(1)). Someone who paints graffiti on a fancy glass window or throws a rock breaking that window may be found guilty of "mischief over $\$ 5,000$ " (Criminal Code, section 430(3)). These offences are all punishable by up to ten years of imprisonment and may lead to the loss of permanent residency and thus to deportation, regardless of the sentence actually received.

Similarly, while sentencing varies substantially depending on circumstances, there are many offences that may reasonably lead to a sentence of six months of imprisonment. For instance, being found guilty by indictment of possession of cocaine, crack, or MDMA can lead to up to seven years of imprisonment, while being found guilty summarily of a second possession offence for these drugs can easily lead to up to a year (CDSA, sections 4(3) and (4)). Not surprisingly then, trafficking any 
drug listed in the Controlled Drugs and Substances Act carries maximum penalties of more than a year (CDSA, section 5) and can easily lead to a sentence of six month or more. The category "serious criminality" as it appears in the IRPA is therefore less a description of the acts that are committed and more a rhetorical device that is used to portray some people as "foreign criminals".

The four above-mentioned points suggest that these harsh criminal inadmissibility measures for non-citizens contribute to a racist and populist agenda, which seeks to construct the 'other' as a means of excluding them, and of galvanizing support for socially conservative policies. Indeed, the fact that these provisions appear very harsh should not surprise us considering their history. The "serious criminality" provision finds its origins in a 1995 amendment to the previous Immigration Act, which removed the right to appeal a removal order for someone who the Minister of Immigration deemed a "danger to the public", and was put forth as a populist response to a shooting involving non-citizens at the Just Desserts Café in Toronto (Chan, 2005; Pratt, 2012). The Just Desserts case became the symbol of the discursive criminalization of immigration in the mid-1990s and a turning point in anti-immigration rhetoric in political discourse. Not surprisingly, this shift took place in a period that also saw significant repressive changes - at least at the level of political discourse - in criminal justice policy, such as the introduction of new mandatory minimum sentences (Doob and Webster, 2006).

Later, in 2012-2013, while another anti-immigrant and tough-on-crime government was in power (Walia and Chu, 2015; Shook et al., 2017), people deemed inadmissible under section 36(1) of the IRPA lost the right to claim asylum, and those deemed inadmissible after being sentenced to six months of imprisonment or more also lost the right to appeal their removal order. Prior to that, this restriction applied only to people sentenced to two years or more. It is telling that the bills that led to these changes in 2012-2013 were officially given the politically-charged names of Protecting Canada's Immigration System Act and Faster Removal of Foreign Criminals Act. The evolution of this provision has historically been tied to anti-immigrant and tough-on-crime populist moves and, we argue, serves no purpose other than to discursively link immigration to criminality, and to allow for the harsher punishment of non-citizens. 


\section{INADMISSIBILITY AS A FORM OF DOUBLE- PUNISHMENT EVEN BEFORE DEPORTATION}

Our second main argument is that inadmissibility - although grounded in administrative immigration law - should be understood as a form of punishment. Being deemed inadmissible for reasons of criminality generally leads to removal from the country, although there are many instances for which one could be both inadmissible yet irremovable and would stay in the country in a legal limbo. ${ }^{9}$ Deportation is an administrative measure which is not legally a punishment, since it is not managed by criminal law. Yet, the practice resembles exile, one of the oldest and harshest forms of punishment in history (Walters, 2002), and, when added at the end on a criminal sentence, it is often analyzed as a form of double punishment. Sayad (2004) coined the concept of double punishment to criticize the fact that non-citizens who have already been punished in a criminal court - and "served their time" - would be "punished" again through deportation once released from prison. We add to this scholarship by arguing that the punitive nature of criminal inadmissibility starts before deportation even takes place and that it is lived as a form of punishment regardless of whether deportation actually occurs at the end.

In Canada, people facing criminal inadmissibility and awaiting deportation can be placed in one of the three dedicated immigration detention centres - officially called "holding centres" - in or near Montreal, Toronto, and Vancouver. They may also be caged in a provincial jail cell rented out and paid for by the Canada Border Services Agency (CBSA) for the purpose of immigration detention. As there is no limit on the length of immigration detention in Canada, people are sometimes detained for months or years, even when their deportation order has nothing to do with a criminal sentence (End Immigration Detention Network, 2014; Cleveland, 2015; Global Detention Project, 2018). However, people can also be released into the community until the bureaucratic steps are fulfilled to enforce the removal order. Indeed, given that immigration detention is supposed to be a measure of last resort to manage people without status, an Immigration and Refugee Board (IRB) commissioner can release them pending deportation after evaluating that they do not constitute a "flight risk" or a danger to the public, or by judging that these jeopardies are manageable by the state via conditions of release. 
People in this situation are usually waiting for the CBSA to obtain travel documents from their embassies to be put on a plane out of Canada. The delays to obtain these documents can range from weeks to years. Therefore, the wait periods, as well as the whole process, are outside of targeted people's control. They are equally powerless vis-à-vis the realities that these processes create for them, but they nonetheless have to live with the adversity generated by the precariousness of their status.

One of the key issues arising from the limbo they experience is that, since their permanent resident status (or other immigration permit) has been revoked, they cannot work legally and thus generate an income. This, in turn, makes it difficult for them to have enough money to respect the very conditions imposed upon them for their release. For instance, how can they travel to report to their CBSA agent weekly - a common condition of release from immigration detention - if they do not have enough money for a bus fare? Furthermore, how can they apply for a stay on deportation, or the authorization to remain in the country based on Humanitarian \& Compassionate Grounds - two expensive and uncertain processes - if they cannot afford legal counsel or the administrative fees?

Based on Souheil's lived experience, we argue that this added stress negatively influences their affective and emotional state, which can be experienced as an administrative form of punishment. We extend this argument in three ways: 1) parole and immigration bail conditions are an extension of the punishment of incarceration; 2) the prohibition from working and the lack of access to healthcare is dehumanizing and lived as a form of punishment; and 3) the strain imposed on the family further expands the carceral and penal net to loved ones.

\section{Parole and Immigration Bail Conditions as Condition-Based Double Punishment}

Although being released while awaiting removal might seem like a gift offered by the state, when we look critically at the lived realities of people awaiting deportation in the community, we find that the freedom of conditional release is in fact a form of broader in-community immigration detention. The streets become the jail and the shelter becomes the cell. Surveillance and control are at the heart of state apparatuses of conditional release, and the carceral logic and punitive nature of imprisonment, parole and bail operate within a continuum of control. The conditions imposed 
by the Parole Board of Canada (PBC) become the carceral spillover of the prison into society. As Souheil explains:

While I was incarcerated in the penitentiary, I was subjected to rules that forced me to behave within a certain code of conduct established by the state. For example, I was not allowed to smoke cannabis and/or consume alcohol. Outside, the same rules were imposed on me as "Special Conditions". On my Statutory Released Certificate, number U3CA00041672, it states clearly that I am not allowed to consume drugs and alcohol. Inside the fences and walls of the prison, if I had been caught smoking and/or drinking, the authorities would have increased my security rating, which would have potentially resulted in a reclassification to maximum security prison and/or a stint in solitary confinement. Therefore, transgressing the prison rules and regulations would have resulted in harsher punishment. While on parole, breaking the state-imposed special conditions would result in a parole violation and in me being forced to spend time behind bars.

As illustrated above, for criminalized individuals, the logics and practices of punishment spill over into the community through various other means of surveillance and conditional liberty.

Just like parole can be seen as an extension of the prison, immigration bail should be understood as the extension of immigration detention. If, as Simon (1993, p. 11) argued, individuals on parole are located "at the border between prisons and the community", people on immigration bail are still in a way caught in the border, neither accepted by the state as a formal member of the political community, nor expelled from it. In this sense, laws that provide for the conditional presence of non-citizens into the country can be understood as forms of immigration probation (Moffette, 2014). The conditions of immigration bail are thus added on top of those imposed by the PBC and the loss of status due to inadmissibility puts further restrictions of what people can do. Souheil describes his situation:

I have various conditions imposed by the Parole Board: I cannot consume drugs or alcohol, cannot travel outside of a perimeter, have to report to the police station monthly, have to do volunteer work, had to respect a curfew for the first while, and the like. As though these conditions were not enough, I also have to report to the law enforcement department of the 
CBSA weekly and fulfil other conditions. It's hard enough to live under these conditions and try to build a life in the community, but by stripping me of my permanent resident status and preventing me to apply for other permits as I am deemed inadmissible, the Canadian state also keeps me in a state of limbo - I am not allowed to work or study and cannot apply for a visa to do so, I lost my access to public healthcare and cannot get it back, I cannot get new ID cards and cannot therefore open a bank account. I experience these limits on what I can do - and the looming threat of deportation - as forms of punishment.

In this case - as in the case of most people facing criminal inadmissibility - two separate government bodies are therefore imposing two separate sets of conditions.

We conceptualize this double punishment as a condition-based double punishment, one that is a consequence of how immigration law and criminal law relate to, reinforce, and inform, each other. Indeed, this punishment is directly linked to two interrelated lists of conditions - one set issued by the PBC and another issued by the IRB - that may be experienced as two sets of restrictive and punitive measures. This is an interrelated and mutually reinforcing form of double punishment, as conditions imposed by the PBC (e.g. spatial conditions of release) intersect with the conditions issued by the IRB (e.g. the mandatory weekly sign-ins) to create a punitive and constricting environment for the person on parole and immigration bail awaiting removal.

\section{The Prohibition on Work and}

\section{Lack of Access to Healthcare as Punishment}

Some of these conditions can also be experienced as dehumanizing, affecting one's sense of agency, and as profoundly unjust and exploitative. This is certainly the case for Souheil:

I experienced immigration bail as a form of slavery. One of my IRBimposed conditions is the prohibition to seek or obtain a paid job while being expected to put in at least 20 hours of volunteer work a week. Through conditions of release, the Canadian state is able to forcefully extract free labour from my body. Because of the heavy-laden conditions of release, which constrain my movement and freedom, I feel as if my 
body is the property of the state. Given that I paid for a lawyer to be released, who contributes to the income tax system, and that I am forced to consume goods and services subject to the Harmonized Sales Tax and Goods and Services Tax in order to survive, I contribute to the Canadian social safety net without benefiting from it. My labour is desired and my legal limbo is a forced subsidy to the Canadian system, but my body is controllable, surveillable and disposable.

The obligation to work voluntarily, while being prohibited from contracting formal employment, coupled with the lack of access to health care, can also have a negative impact on one's health, which increases the experience of these conditions as a form of punishment. Souheil explains:

Combined with the exclusion from the public healthcare, the prohibition from paid work is a violent attack on my psychological and physical health. Often, I have found myself starving with no money in my pocket. The hunger was a direct consequence of my inability to obtain a remuneration for my work. My weight and mental state fluctuate with the amount that my family and friends can contribute to my diet. I often feel the punitive attacks of the state in my gut. I also feel like a burden on my family and my friends. I am thankful that my extended family regularly sends me remittances from Africa. I feel dehumanized and stripped from a substantial part of my agency. I often start anxiously thinking about how the conditions of release that prohibit migrants from providing the strict minimum for their survival and for their children is a violent attack on their physical and mental health. The inability to provide for my son is infantilizing. Anxiety, hunger and anger become a poisonous cocktail I taste every time I run low on my already-scarce financial resources. While the Canadian government's immigration laws contribute to the deterioration of migrants' health, the government does not provide health coverage to those individuals living on Canadian soil and awaiting deportation. The deterioration of my mental health is consequential of how the Canadian systems discriminate against me based on my status.

While there is research on the negative psychological impact of immigration detention (Cleveland and Rousseau, 2013; von Werthern et al., 2018), there is limited research on the consequences of being forced 
to live without status. Not surprisingly, however, the research that does exist confirms that it is detrimental to mental health (Bernhard et al., 2007; Simich et al., 2007; Saad, 2012). In the case of former permanent residents deemed inadmissible, the state actively strips them of their status, contributing directly to the harm caused.

It is known that criminalization, through stigmatization, limits the ability of all those who have been criminalized to work, be self-sufficient and move on with their lives (Lopez-Aguado, 2016). Through criminal inadmissibility, the Canadian immigration system further exacerbates this marginalization created by the penal system. While we cannot demonstrate whether there is an intent to use these limits on one's basic rights as a means to further punish people awaiting deportation, the fact that it is experienced as the infliction of pain - a central component of the notion of punishment - is sufficient, in our view, to consider that it qualifies as a form of punishment.

\section{The Impact on Families}

This strain is also often experienced by families. This is the case for prisoners whose incarceration also punishes their loved ones by association (Lehalle, 2019). Conditional releases, by imposing strict conditions, uncertainty and surveillance on people who live in the community, also has the effect of expanding the carceral net (Jiwani, 2011), capturing family members who are not officially targeted by them, while also enrolling them in state control work (Larsen et al., 2008).

The consequences can take many forms. One of them is financial. As they are subjected to structural abandonment in Canada, racialized folks are often marginalized economically, even when they are skilled and have post-secondary education (Maynard, 2017). The socioeconomic situation of Souheil's family accords to this reality:

To ensure my release, my parents were forced to borrow beyond their means to hire a competent lawyer, pay the $\$ 5,000$ immigration cash bond required by the IRB, and cover for the other expenses related to welcoming me back into their home, such as travel and hotel expenses to be present at the hearings and to testify as sureties or guarantors. The feeling of being beholden to my parents and the knowledge that I cannot relieve them from the inconveniences caused by their benevolent, yet heavy-laden service generated a sense of helplessness. 
Access to conditional release is a deeply classed remedy that is not accessible to many and is experienced differently according to class position.

Another series of consequences are emotional and tied to a loved one's uncertain presence in Canada and the continuous threat of deportation. As Souheil explains:

The all-consuming fear of being separated from my 8-year-old Canadian child further exacerbates my anxiety and has detrimental consequences on my mental health and that of my child. On numerous occasions my son expressed to me, sometimes in tears, how my imminent deportation is scaring him. Besides being a double punishment for me, criminal inadmissibility is a punishment for my whole family, who are all Canadian citizens. Criminal inadmissibility becomes then a multi-party double

punishment, meaning that not only does it punish the individuals who are deemed inadmissible, it also punishes their families and social circles. Besides my family, who clearly iterated how my legal limbo and removal is harming and will harm them, several of my friends and colleagues, some of which I met while awaiting removal, conveyed to me that they would rather not think about my deportation, because it is a stressful thought that generates anxiety and mental distress for them.

The impact on children and parents takes many forms. Parents who are in immigration detention and who do not have other family members in the country to look after their child may "choose" to have them live with them in detention or have to put them in the care of the Children's Aids Society (End Immigration Detention Network, 2014; Gros, 2017). In other cases, women on immigration bail may be forced to live in abusive relationships because of bail conditions, and may lack the ability to seek alternative living conditions for themselves and their children due to their precarious immigration status (Bhuyan, 2012; Abji, 2016). The harm generated is therefore also often gendered.

\section{CRIMINAL INADMISSIBILITY PROVISIONS AS A DISCRETIONARY POLICING TOOL}

Our final point is that the fact that criminal law and immigration law are governed by distinct legal regimes allows the state and police officers to 
cherry-pick what legal provisions they will use to govern and punish noncitizens. We see the way discretion is used in this context as problematic. This third point is harder to illustrate from the vantage point adopted in this paper - a formal analysis of the way the law is written and the lived experience of one of the co-authors - as it would require studying policing practices. We will therefore present it more concisely, drawing from cases for which it is more obvious.

It is important to note that inadmissibility is not the automatic result of a criminal sentence that falls under sections 36(1) and 36(2) of the IRPA. The CBSA first needs to decide to report the criminalized person to the Minister of Immigration, Refugees and Citizenship. Then, the Minister (or their delegate) is the one deciding whether or not to refer the case to the IRB and is supposed to consider whether it is in the interest of the public. If the case is referred, then an IRB commissioner renders a decision on inadmissibility. There are over 1,000 people deported every year from Canada on criminality or serious criminality grounds. ${ }^{10}$ Although the Minister is supposed to exercise discretion in referring cases, data obtained through Access to Information requests reveal that the Minister's delegate refers the case to the IRB systematically, therefore effectively leaving the decision to use this provision in the hands of the CBSA. ${ }^{11}$

This is highly problematic. In the case of Tran Trong Nghi Nguyen - a permanent resident who lost his status after serving "a conditional sentence of two years less a day in the community for [...] drug offences"12 (Pratt, 2012 , p. 273), and who was later deported to Vietnam despite being the only caregiver and provider for his ill mother - Pratt (2012, p. 275) has argued that officials had used this provision to ensure that "immigration enforcement would ultimately succeed where criminal justice had failed". Indeed, this immigration provision which requires a lower standard of proof was used a posteriori to administratively remove Tran when allegations of involvement in a gang were raised by police, but without sufficient proof to charge him criminally. Here, unable to prosecute him criminally, police officers passed on intelligence that could not amount to evidence in a criminal court to their CBSA colleagues, who could help them ensure Tran's incapacitation through administrative deportation.

Another high-profile case worth mentioning is that of Danny Villanueva, who is the brother of Fredy Villanueva, a young man killed by a Montreal police officer in 2008 during an identification check and search in a park 
where both were hanging out with friends. As Danny was about to testify in the coroner's inquest into his brother's death in 2010, the CBSA filed an inadmissibility request for an offence dating back to 2006 that they had never acted upon (CTV News, 2010). While it is impossible to link his participation in the inquest to the decision to file for inadmissibility four years after the offence, the timing was rather odd. In the end, Danny Villanueva was able to remain in Canada after a Pre-Removal Risk Assessment (PRRA) found that his life would be in danger if he were to be sent back to Honduras, where he had not lived since he was 11 years old (CBS News, 2016). Together, these two examples suggest that the discretionary power of the CBSA to request an assessment of inadmissibility on criminal grounds can be used as one more tool in the policing toolkit, one that can be deployed to further control and punish people who have already served a sentence.

\section{CONCLUSION}

We consider that, as a form of double punishment, criminal inadmissibility should be abolished for all, but even more urgently for permanent residents who differ from citizens in many cases only by the fact that they did not apply for citizenship when they were eligible. If citizens who have served their time can be deemed to have "paid their debt to society", however problematic this assumption is ${ }^{13}$ why should non-citizens face a second punishment by being deported? This provision discriminates against them in a way that we find inacceptable and that resembles what Richmond (1994) and Sharma (2012) have called apartheid: the treatment of a minoritized - and often racialized - group through coercive legal provisions that could not be applied to the (generally white) majority. This racist form of displacement is informed by a history of colonial violence, which is particularly problematic in a settler-colonial state such as Canada.

Our call for the abolition of what we see as a punitive dimension of immigration law responds directly to the hardships and injustices that it produces, but we also see it as a contribution to abolitionists' efforts to broaden our scope of analysis and our political projects. The move from prison abolitionism to penal abolitionism has been underway for a long time now (Piché and Larsen, 2010; Carrier and Piché, 2015), but more work needs to be done to further understand forms of punishment not anchored in criminal law, such as immigration penality (Pratt, 2012). We also situate penal abolitionism 
within the larger breadth of carceral abolitionism, which is the greater struggle that informs our theory and praxis. As discussion and critique of a racialized "global carceralization" (Carrier and Piché, 2015) continue, we argue that abolitionists need to engage seriously with the questions of legal apartheid and global border regimes, while migrant justice activists need to embrace penal and carceral abolitionism. These reflections are already happening, inside and outside, in movements and in academia (Anderson et al., 2009; Anderson, 2013; Walia, 2013; Loyd, 2019). This article is but a small contribution to this conversation, as we imagine and build an abolitionist future that defends the freedom to move to other places to make a better life, the freedom to return to lands that have been colonized and stolen, and the freedom to stay in places where we build communities.

\section{ENDNOTES}

1 While much of the literature discusses this situation mobilizing the concept of "crimmigration" (Stumpf, 2006), we consider that it may not be the best analytical tool. See Moffette (2018) for a discussion of this concept.

2 While we wrote the article together, the biographical sections were written only by Souheil and therefore are written in first person.

3 Other subsections clarify how inadmissibility may also apply to offences having taken place outside of the country. See Section 36 for the specific wording.

4 While recent changes to the Citizenship Act by the Liberal government (through Bill C-6) restored the "three out of five years" rule that prevailed before Harper's Conservatives made it even more restrictive, the bill also ensured that people serving a conditional sentence in the community are not able to count this time as part of their presence requirement. This was already the case for people serving time inside, people on probation and people on parole. Furthermore, no one serving time, on probation or on parole can be granted citizenship (see Citizenship Act, sections 21(c) and 22(1)).

5 This will likely change as a result of the recent legalization regime for cannabis.

6 As previously mentioned, Section 36(1)(a) states that inadmissibility for "serious criminality" applies for two reasons: "having been convicted in Canada of an offence under an Act of Parliament punishable by a maximum term of imprisonment of at least 10 years, or an offence under an Act of Parliament for which a term of imprisonment of more than six months has been imposed". The loss of appeal applies only to the second of these cases, punishment to a term of more than six months (IRPA, 64(2)).

7 A pseudonym.

8 We thank two criminal lawyer friends for their advice on parts of this section of the paper. Of course, any remaining errors in legal interpretation would be ours alone.

9 For instance, some people may be inadmissible, but not deportable because they are stateless, their identity is uncertain, their country of citizenship refuses to recognize 
them or there is a legally recognized risk for their safety if they are returned (see Bond, 2017).

10 Records released by the CBSA through Access to Information (CBSA ATIP file \# A-2016-10866) document about 1,000 removals on those grounds annually for 2015 and 2016. In her article, Bond (2017) reports over 10,000 removals for the 20042014 period, which amounts to approximately 1,000 removals annually.

11 Only one file per year was not transferred to the IRB in 2015 and 2016 (CBSA ATIP File \# A-2017-12736).

12 In a later case involving a different Vietnamese citizen who was also a permanent resident, the Supreme Court of Canada recently ruled that conditional sentences served in the community can no longer be considered as terms of imprisonment for the purpose of immigration law (Tran v. Canada).

13 Here, we point to the double standard that applies within the penal system's own logic, while also rejecting the "paying one's debt to society" justification for punishment. There are several problems with this notion that we can only mention briefly here. 1) Retribution: this notion of "paying one's debt to society" is informed - directly or indirectly - by retributive justifications of punishment derived from the old biblical lex talionis of "an eye for an eye" (Walen, 2016), which we reject. 2) Proportionality: it assumes that the pain inflicted through punishment is proportional to the suffering caused by the offence, an idea that does not hold (see Christie, 1982; Mathiesen, 1990). 3) Removing the victim: while "paying a debt" may point to a more progressive notion of restorative restitution to the victim and the need to make amends, the notion that the debt is to society, not the victim, is representative of how the penal system steals the conflict from the parties involved and appropriates it for itself (Christie, 1977). 4) Society's debt to the person: many people become involved in criminalized, conflictual, and/or harmful acts because of state-sanctioned neglect and violence. The notion of "debt to society" can become a rhetorical tool that dissimulates the state's direct role, and absolve the state's responsibility, in creating social harm and conflict. The state chooses to respond to the harm and conflict it creates by criminalizing the very victims of the violent state-sanctioned carceral modus operandi, which results in the mass criminalization of certain groups, along with the infliction of substantive harm to certain individuals and communities.

\section{REFERENCES}

Abji, Salina (2016) “'Because Deportation is Violence Against Women’: On the Politics of State Responsibility and Women's Human Rights”, Social Politics, 23(4): 483507.

Anderson, Bridget (2013) Us and Them? The Dangerous Politics of Immigration Control, Oxford: Oxford University Press.

Anderson, Bridget, Nandita Sharma and Cynthia Wright (2009) "Why No Borders?", Refuge: Canada's Journal on Refugees, 26(2): 5-18.

Bernhard, Judith K., Luin Goldring, Julie Young, Carolina Berinstein and Beth Wilson (2007) "Living with Precarious Legal Status in Canada: Implications for the WellBeing of Children and Families", Refuge: Canada's Journal on Refugees, 24(2): 101-114. 
Bhuyan, Rupaleem (2012) "Negotiating Citizenship on the Frontlines: How the Devolution of Canadian Immigration Policy Shapes Service Delivery to Women Fleeing Abuse", Law \& Policy, 34(2): 211-236.

Bond, Jennifer (2017) "Unwanted but Unremovable: Canada's Treatment of 'Criminal' Migrants Who Cannot be Removed”, Refugee Survey Quarterly, 36(1): 168-186.

Carrier, Nicolas and Justin Piché (2015) "The State of Abolitionism", Champ Pénal/ Penal Field, 12.

CBC News (2016) "Dany Villanueva Will Be Allowed to Stay in Canada", CBC News. Retrieved from <https://www.cbc.ca/news/canada/montreal/dany-villanuevadeportation-1.3467005>.

Chan, Wendy (2005) "Crime, Deportation and the Regulation of Immigrants in Canada", Crime, Law and Social Change, 44(2): 153-180.

Chan, Wendy and Dorothy Chunn (2014) Racialization, Crime and Criminal Justice in Canada, Toronto: University of Toronto Press.

Cleveland, Janet (2015) "Not so Short and Sweet: Immigration Detention in Canada", in Amy Nethery and Stephanie J. Silverman (eds.), Immigration Detention: The Migration of a Policy and its Human Impact, New York: Routledge, pp. 79-87.

Cleveland, Janet, and Cécile Rousseau (2013) "Psychiatric Symptoms Associated with Brief Detention of Adult Asylums Seekers in Canada", Canadian Journal of Psychiatry, 58(7): 409-416.

CTV News (2010) "Dany Villanueva Facing Deportation", CTV News. Retrieved from $<$ https://montreal.ctvnews.ca/dany-villanueva-facing-deportation-1.478281>.

Christie, Nils (1977) "Conflict as Property”, British Journal of Criminology, 17(1): 1-15.

Christie, Nils (1982) Limits to Pain, Oxford: Martin Robertson.

Doob, Anthony N. and Cheryl Marie Webster (2006) "Countering Punitiveness: Understanding Stability in Canada's Imprisonment Rate", Law \& Society Review, 40(2): 325-367.

El-Lahib, Yahya (2015) “The Inadmissible 'Other': Discourses of Ableism and Colonialism in Canadian Immigration", Journal of Progressive Human Services, 26(3): 209-228.

End Immigration Detention Network (2014) Indefinite, Arbitrary and Unfair: The Truth about Immigration Detention in Canada, Toronto.

Global Detention Project (2018) Country Report - Immigration Detention in Canada: Important Reforms, Ongoing Concerns, Geneva.

Gros, Hanna (2017) Invisible Citizens: Canadian Children in Immigration Detention, Toronto: International Human Rights Program, Toronto: University of Toronto Faculty of Law.

Gurmukh, Sunil (2018) "Interrogating the Definition of Racial Profiling: A Critical Legal Analysis", in Lorne Foster, Lesley A. Jacobs, Bobby Siu and Shaheen Azmi (eds.), Racial Profiling and Human Rights in Canada: The New Legal Landscape, Toronto: Irvin Law, pp. 59-88.

Jiwani, Yasmin (2011) "Trapped in the Carceral Net: Race, Gender, and the 'War on Terror"”, Global Media Journal - Canadian Edition, 4(2): 13-31.

Larsen, Mike, Sophie Harkat and Mohamed Harkat (2008) "Justice in Tiers: Security Certificate Detention in Canada", Journal of Prisoners on Prisons, 17(2): 31-46.

Lehalle, Sandra (2019) "Le ricochet carcéral chez les proches des personnes incarcérées", Criminologie, 52(1) : 9-18. 
Lopez-Aguado, Patrick (2016) "The Collateral Consequences of Prisonization: Racial Sorting, Carceral Identity, and Community Criminalization", Sociology Compass, 10(1): 12-23.

Loyd, Jenna M (2019) "Prison Abolitionist Perspective on No Borders", in Nick Heynen and Reece Jones (eds.), Open Borders: In Defense of Free Movement, Athens, Georgia: University of Georgia Press, pp. 89-109.

Mathiesen, Thomas (1990) Prison on Trial, London: Sage.

Maynard, Robyn (2017) Policing Black Lives: State Violence in Canada from Slavery to the Present, Black Point, Halifax: Fernwood.

Moffette, David (2014) "Governing Immigration through Probation: The Displacement of Borderwork and the Assessment of Desirability in Spain", Security Dialogue, 45(3): 262-278.

Moffette, David (2018) “The Jurisdictional Games of Immigration Policing: Barcelona's Fight Against Unauthorized Street Vending", Theoretical Criminology (Online First), 1-18.

Piché, Justin and Mike Larsen (2010) "The Moving Targets of Penal Abolitionism: ICOPA, Past, Present and Future", Contemporary Justice Review, 13(4): 391-410.

Pratt, Anna (2012) "Immigration Penality and the Crime-Security Nexus: The Case of Tran Trong Nghi Nguyen", in Karim Ismaili, Jane B. Sprott and Kim Varma (eds.), Canadian Criminal Justice Policy: Contemporary Perspectives, Oxford: Oxford University Press, pp. 273-298.

Richmond, Anthony H. (1994) Global Apartheid: Refugees, Racism, and the New World Order, Oxford: Oxford University Press.

Saad, Samia (2012) "The Cost of Invisibility: The Psychosocial Impact of Falling Out of Status", in Luin Goldring and Patriciat Landolt (eds.), Producing and Negotiating Non-Citizenship: Precarious Legal Status in Canada, Toronto: Toronto University Press.

Sayad, Abdelmalek (2004) The Suffering of the Immigrant, Cambridge: Polity Press.

Sharma, Nandita (2012) "Nation States, Borders, Citizenship, and the Making of 'National' Difference", in Deborah Brock, Rebecca Raby and Mark P. Thomas (eds.), Power and Everyday Practices, Toronto: Nelson, pp. 321-342.

Shook, Jarrod, Bridget McInnis, Justin Piché and Kevin Walby (eds.) (2017) Special Issue - Dialogue on Canada's Federal Penitentiary System and the Need for Change, Journal of Prisoners on Prisons, 26(1\&2): 1-302.

Simich, Laura, Fei Wu and Sonia Nerad (2007) "Status and Health Security: An Exploratory Study of Irregular Immigrants in Toronto", Canadian Journal of Public Health, 98(5): 369-373.

Simon, Jonathan (1993) Poor Discipline: Parole and the Social Control of the UnderClass, 1890-1990, Chicago: University of Chicago Press.

Stumpf, Juliet (2006) "The Crimmigration Crisis: Immigrants, Crime, and Sovereign Power", American University Law Review, 56(2): 367-419.

Tavadian, Alexandre (2010) Statutory, Judicial and Administrative Stays in Immigration Matters, Toronto: Carswell.

von Werthern, Martha, Katy Robjant, Zoe Chui, Rachel Schon, Livia Ottisova, Claire Mason and Cornelius Katona (2018) "The Impact of Immigration Detention on Mental Health: A Systematic Review”, BMC Psychiatry, 18(382): 1-19. 
Walen, Alec (2016) "Retributive Justice", in Edward N. Zalta (ed.), The Stanford Encyclopedia of Philosophy. Retrived from $<$ https://plato.stanford.edu/archives/ win2016/entries/justice-retributive/>.

Walia, Harsha (2013) Undoing Border Imperialism, Oakland: AK Press.

Walia, Harsha and Omar Chu (2015) Never Home: Legislating Discrimination in Canadian Immigration (Report for No One Is Illegal-Vancouver. Unceded Coast Salish Territories), Vancouver: NOII.

Walters, William (2002) "Deportation, Expulsion, and the International Police of Aliens", Citizenship Studies, 6(3): 265-292.

Wilton, Robert, Stine Hansen and Edward Hall (2017) "Disabled People, Medical Inadmissibility, and the Differential Politics of Immigration", The Canadian Geographer, 61(3): 389-400.

\section{Legislation Cited}

Citizenship Act, RSC 195, c C-29.

Controlled Drugs and Substances Act, SC 1996, c 19.

Convention Relating to the Status of Refugees, 189 UNTS 150, 28 July 1951.

Immigration Act, 1976-77, c 52, s1.

Immigration and Refugee Protection Act, SC 2001, c 27.

Faster Removal of Foreign Criminal Act, SC 2013, c. 16.

Protecting Canada's Immigration System Act, SC 2012, c 17.

\section{Case Cited}

Tran v Canada (Public Safety and Emergency Preparedness), 2017 SCC 50.

\section{ABOUT THE AUTHORS}

Souheil Benslimane is an illegalized and criminalized migrant who is currently awaiting imminent deportation to Morocco. After serving a federal sentence and being released from immigration detention in March 2018, he became involved in abolitionist, as well as prisoner and migrant justice organizing, as a member of the Criminalization and Punishment Education Project (CPEP), a member of the Ottawa Sanctuary City Network (OSN), and the Coordinator of the Jail Accountability \& Information Line (JAIL).

David Moffette, $P h D$ is Assistant Professor in the Department of Criminology at the University of Ottawa. His research looks at the intersections of immigration law and criminal law, policing, borders, and race and racism. He has been active in migrant justice and social justice movements for 15 years. 